\title{
Hepato-osteodystrophic syndrome at ewes in the East of Ukraine
}

\author{
P. Sharandak,
}

Docent, cand. of vet. science, Institute of Veterinary Medicine NAAS

\author{
V. Levchenko, \\ Academic of NAAS, doctor of vet. science, \\ Bila Tserkva State Agrarian University
}

The purpose. To study spread and to determine diagnostic criteria of hepato-osteodystrophic syndrome at ewes in the East of Ukraine. Methods. Laboratory, biochemical, statistical. Results. Spread of joint pathology of liver and calcium-phosphoric exchange at ewes in the East of Ukraine, as well as the cause of origination and diagnostic criteria is studied. Conclusions. Hepato-osteodystrophic syndrome is spread at $7,6 \%$ of ewes. The cause of this pathology is imbalance of rations. The most informative parameters of that syndrome are: hypocalcemia $(100 \%)$, hypoalbuminemia $(79,3 \%)$, hyper- $\gamma$-globulinemia $(44,8 \%)$, and hyperactivity of GGTP $(48,3 \%)$.

Key words: sheep, hepato-dystrophy, osteo-dystrophy, polymorbid pathology, diagnostics, calcium, $\gamma$ glutamile-transpeptidase.

Statement of problem. Metabolic disorders that are caused by the insecurity or unbalanced rations by the nutrients and bioactive substances, the failure mode of feeding and intake structures, often lead to the development of osteodystrophy, A- and D-vitamin deficiency, hypocalcemia and hypophosphatemia postpartum, liver disease (fatty hepatodystrophy) heart (myocardial), digestive system (hypotension and acidosis rumen, abomasum displacement) which have a common etiology and pathogenesis. Combined progress of these diseases is called multiple (polimorbid) pathology. Very often the multiple organ and polimetabolic pathology are observed in animals. These pathologies are partially studied among others cattle diseases. [1, 2].

Sheep diseases are not enough studied in Ukraine. The main attention was dedicated to the ketosis of ewes and sheep microelementosis in the Polissia conditions [3] and also the the experimentally caused hepatodystrophy [4]. Only I. Senchuk thesis (2009) describes the ewes ketosis as a polimorbid pathology (in conjunction with hepatodystrophy) [5].

The purpose of research to study the distribution and define diagnostic criteria of the hepatoosteodystrofic syndrome in the Eastern Ukraine population of ewes.

Materials and methods of researches. The subject of the study was the ewes originated from the Luhansk region, Krasnodon, Lutuhino, Markov, Slavyanoserbsk and Troitsky districts.

All samples of feed were tested for copper, zinc, manganese, Lead and cadmium contain using the atomic absorption spectral analysis in the Lugansk regional state laboratory for veterinary medicine [6].

Analysis of feed rations was conducted according to the rules specified in references [7,8], and based on the own calculations of the fat, sugar and starch needs for animals considering chemical feed composition grown in the Luhansk region. [9].

The total protein was measured in the animals serum using biuret method and its fractions by nephelometric method, total calcium content was detected in the reaction with arsenazo complex III), inorganic phosphorus was detected by the fosfomolibdat method) [10]. The activity of serum aspartic (AST) and alanine (ALT) aminotransferases was defined by the Raytman-Frenkel, gammaglutamil-transpeptidase (GGT) - by Szaz [11].

The content of copper, zinc, manganese in the serum was determined by atomic absorption spectral analysis [6]. 
The obtained results were the subject for the variation statistics method treatment. We determined the arithmetic mean $(M)$, the statistical error arithmetic mean $(m)$, the probability of the difference between the arithmetic mean of the two series in variation criterion probability $(p)$ and the Student table. The difference between the two values considered probable for $p<0,05 ; 0,01$ and 0,001 .

Results. The tests of the ewes originated for five districts showed that $7.6 \%$ of the observed liver damage occurres in conjunction with osteodystrophy (hepatoosteodystrofic syndrome). Animal feed analysis is very important for internal pathology diagnostic.

Feeds from 5 farms of the Lugansk region, where the studies were conducted contained essential sufficient number of trace elements, and lead and cadmium concentration did not exceed the maximum permissible concentration (MPC) - 10,0 and $0,7 \mathrm{mg} / \mathrm{kg}$, respectively.

Ewes' feed rations analysis set down unbalanced diet structure; an exceed number of dry matter in combination with a low concentration of metabolic energy, crude and digestible protein, sugar, starch, calcium (in 4 districts), phosphorus, sulfur, copper, zinc, manganese and iodine in $1 \mathrm{~kg}$ of dry matter of feed; low ratio between easyfermented carbohydrates (starch and sugar) and digestible protein that can cause liver disease and generate the development of calcium and phosphorus ratio damage.

Hepatoosteodystrofic syndrome (HODS) is a consequence of the hepatodystrophy which causes the infraction of the $25(\mathrm{OH}) \mathrm{D} 3$ and bile acids synthesis, bile secretion, absorption of vitamin $\mathrm{D}$, calcium and phosphorus decreases. The deficit of $1,25(\mathrm{OH})_{2} \mathrm{D}_{3}$-dyhydroxyholecalciferol causes a reduction in calcium and phosphorus reabsorption in the kidneys and calcium jointing protein synthesis in the gut. Consequently the D-vitamin and calcium-phosphorus metabolism is interrupted and joint pathology such as hepatoosteodystrofichny syndrome is developing, which finally must be considered as hepato-osteorenalnyy.

Hepatoosteodystrofic syndrome is characterized by development of osteodystrophy in animals with damaged liver. In $44,4 \%$ of idle ewes developed hypoproteinemia the amount of common protein in serum blood decreased to $61,5 \pm 1,65 \mathrm{~g} / \mathrm{l}(\mathrm{p}<0,05)$ against $35,1 \pm 0,47 \mathrm{~g} / \mathrm{l}$ at norm. Common pathology of liver and calcium-phosphorus exchange is characterized by hypoalbuminemia in $70,0 \%$ of lactation ewes $(28,7-43,8 \% ; 37,8 \pm 0,97)(p<0,001)$ and decreasing part of gamma-globulins in $45,0 \%$ of animals $(37,1 \pm 0,95 \% ; 30,2-45,8)(p<0,001$; table 1$)$.

Table 1. Status of protein exchange ewes with HODS

\begin{tabular}{|c|c|c|c|c|c|c|c|}
\hline \multirow{2}{*}{\multicolumn{2}{|c|}{ Group of animals }} & \multirow{2}{*}{$\begin{array}{l}\text { Common } \\
\text { protein, } \\
\text { g/l }\end{array}$} & \multicolumn{5}{|c|}{ Protein fractions, in \% } \\
\hline & & & Albumen & $\begin{array}{l}\alpha_{1}^{-} \\
\text {globulins }\end{array}$ & $\begin{array}{l}\alpha_{2^{-}} \\
\text {globulins }\end{array}$ & $\beta$-globulins & $\gamma$-globulins \\
\hline \multicolumn{8}{|l|}{ Lactating } \\
\hline $\begin{array}{l}\text { Clinically } \\
\text { healthy }(n=20)\end{array}$ & $\begin{array}{l}\operatorname{Lim} \\
M \pm m\end{array}$ & $\begin{array}{l}60,4-71,4 \\
64,1 \pm 1,56\end{array}$ & $\begin{array}{l}40,5-50,0 \\
44,5 \pm 0,07\end{array}$ & $\begin{array}{l}4,2-12,3 \\
8,0 \pm 0,38\end{array}$ & $\begin{array}{l}4,9-9,6 \\
6,7 \pm 0,36\end{array}$ & $\begin{array}{r}4,9-18,1 \\
11,8 \pm 0,66\end{array}$ & $\begin{array}{l}20,8-35,3 \\
30,0 \pm 1,22\end{array}$ \\
\hline $\operatorname{HODS}(n=20)$ & $\begin{array}{l}\operatorname{Lim} \\
M \pm m \\
p<\end{array}$ & $\begin{array}{l}52,7-74,5 \\
64,9 \pm 1,39 \\
0,1\end{array}$ & $\begin{array}{l}28,7-43,8 \\
37,8 \pm 0,97 \\
0,001\end{array}$ & $\begin{array}{l}2,8-10,3 \\
6,8 \pm 0,47 \\
0,1\end{array}$ & $\begin{array}{l}3,2-8,4 \\
6,3 \pm 0,34 \\
0,5\end{array}$ & $\begin{array}{r}8,5-20,5 \\
12,0 \pm 0,69 \\
0,5\end{array}$ & $\begin{array}{l}30,2-45,8 \\
37,1 \pm 0,95 \\
0,001\end{array}$ \\
\hline \multicolumn{8}{|l|}{ Idle } \\
\hline $\begin{array}{l}\text { Clinically } \\
\text { healthy }(n=7)\end{array}$ & $\begin{array}{l}\operatorname{Lim} \\
M \pm m\end{array}$ & $\begin{array}{l}64,1-71,4 \\
65,1 \pm 0,47\end{array}$ & $\begin{array}{l}41,7-46,8 \\
44,0 \pm 0,39\end{array}$ & $\begin{array}{l}4,1-14,5 \\
8,2 \pm 1,32\end{array}$ & $\begin{array}{l}3,1-11,6 \\
6,3 \pm 1,06\end{array}$ & $\begin{array}{r}6,2-18,1 \\
11,4 \pm 0,39\end{array}$ & $\begin{array}{l}25,0-35,6 \\
31,0 \pm 1,35\end{array}$ \\
\hline $\operatorname{HODS}(n=9)$ & $\begin{array}{l}\operatorname{Lim} \\
M \pm m \\
p<\end{array}$ & $\begin{array}{l}55,5-68,3 \\
61,5 \pm 1,35 \\
0,05\end{array}$ & $\begin{array}{l}34,2-41,7 \\
37,4 \pm 0,83 \\
0,001\end{array}$ & $\begin{array}{l}4,2-10,3 \\
7,2 \pm 0,57 \\
0,1\end{array}$ & $\begin{array}{l}2,3-7,6 \\
5,4 \pm 0,51 \\
0,1\end{array}$ & $\begin{array}{r}6,4-14,5 \\
10,6 \pm 0,85 \\
0,1\end{array}$ & $\begin{array}{l}30,0-55,2 \\
39,4 \pm 1,59 \\
0,001\end{array}$ \\
\hline
\end{tabular}

Note. $p<0,5 ; p<0,1 ; p<0,05 ; p<0,001$, in accordance with group of clinically healthy animals.

Condition of protein exchange under hepatoosteodystrofic syndrome is characterized mostly by normal concentration in serum blood common protein (62,07\%), hypoalbuminemia (in 79,3\%) and decreasing fraction of gamma-globulins in $44,8 \%$ of sick ewes. One animal with HODS (3,45 \%) concentration of common protein and ratio between its fractions were in physiological indexes.

Hepatoosteodystrofic syndrome is developed by expectance $(p<0,05)$ increasing activity of gammaglutamiltranspeptidase of lactating to $64,3 \pm 3,00$ and idle $-94,2 \pm 11,04 \mathrm{U} / \mathrm{l}$ ewes. Hyperactivity of 
enzyme was appeared respectively in 5,0 and $66,7 \%$ of sick animals. Changes in activity of alanine and asparagine transpherase were not respective (table 2).

Table 2. Activity of enzymes in serum blood of ewes ill with HODS

\begin{tabular}{|c|c|c|c|c|}
\hline Group of animals & $\begin{array}{l}\text { Biometric } \\
\text { indexes }\end{array}$ & ALT, mmol $\times$ hour/l & $\begin{array}{l}\text { AST, } \\
\text { mmol } \times \text { hour/l }\end{array}$ & GGT, U/I \\
\hline \multicolumn{5}{|l|}{ Lactating } \\
\hline Clinically healthy & $\begin{array}{l}\operatorname{Lim} \\
M \pm m\end{array}$ & $\begin{array}{l}0,16-1,35 \\
0,53 \pm 0,08\end{array}$ & $\begin{array}{l}1,15-2,56 \\
1,62 \pm 0,07\end{array}$ & $\begin{array}{l}16,1-85,9 \\
50,4 \pm 4,61\end{array}$ \\
\hline Animals with HODS & $\begin{array}{l}\operatorname{Lim} \\
M \pm m \\
p<\end{array}$ & $\begin{array}{l}0,38-0,91 \\
0,63 \pm 0,04 \\
0,5\end{array}$ & $\begin{array}{l}1,36-2,18 \\
1,79 \pm 0,06 \\
0,1\end{array}$ & $\begin{array}{l}37,4-85,3 \\
64,3 \pm 3,00 \\
0,05\end{array}$ \\
\hline \multicolumn{5}{|l|}{ Idle } \\
\hline Clinically healthy & $\begin{array}{l}\mathrm{Lim} \\
\mathrm{M} \pm \mathrm{m}\end{array}$ & $\begin{array}{l}0,07-0,83 \\
0,46 \pm 0,11\end{array}$ & $\begin{array}{l}1,34-2,04 \\
1,65 \pm 0,10\end{array}$ & $\begin{array}{l}23,1-76,3 \\
56,1 \pm 7,41\end{array}$ \\
\hline Animals with HODS & $\begin{array}{l}\text { Lim } \\
M \pm m \\
p<\end{array}$ & $\begin{array}{l}0,17-0,93 \\
0,48 \pm 0,09 \\
0,5\end{array}$ & $\begin{array}{l}1,09-2,12 \\
1,69 \pm 0,12 \\
0,5\end{array}$ & $\begin{array}{l}52,3-151,2 \\
94,2 \pm 11,04 \\
0,01\end{array}$ \\
\hline
\end{tabular}

Note. $p<0,5 ; p<0,1 ; p<0,05 ; p<0,01$, in accordance with group of clinically healthy animals.

The most appealable reasons under hepatoosteodystrofic syndrome in serum blood of sheep were changes in activity of gammaglutamiltranspeptidase (GGT), that means about damage of cholic ducts in liver of sheep, because enzyme is situated in cells of their endothelium [6].

Under HODS, in $100 \%$ of ewes was set hypocalcaemia $(p<0,001)$ : amount of calcium is $2,26 \pm 0,02(2,06-2,36)$ in lactating and 2,22 $\pm 0,03 \mathrm{mmol} / \mathrm{l}(2,06-2,35)$ in idle. Level of nion-organic phosphorus don't change $(p<0,5)$.

Beside research of amount in serum blood common calcium and non-organic phosphorus, important thing is researching condition of microelement exchange, that influence on exchange in bone tissue.

Under hepatoosteodystrofic syndrome concentration of Manganese in serum blood of sick lactating sheep relatively to clinically healthy apparently $(p<0,05)$ increase to $1,25 \pm 0,01 \mu \mathrm{mol} / \mathrm{l}(0,88-1,51)$. Amount of Zinc, in blood of lactating ewes with sighs of complex pathology of liver and calcium-phosphorus exchange were stabile $(14,3-19,1)$, and idle are characterized by tendency to decreasing $(15,9 \pm 0,29 \mu \mathrm{mol} / \mathrm{I})$ in accordance to indexes of clinically healthy sheep (15,6-18,2 $\mu \mathrm{mol} / \mathrm{l})$. Zinc deficiency was charactered for $22,2 \%$ sick lactating and idle animals. Amount of copper in serum blood of sick ewes with reasons of hepatoosteodystrofic syndrome, apparently $(p<0,5)$ and not different with indexes of clinically healthy sheep and consist of $11,2 \pm 0,37 \mu \mathrm{mol} / \mathrm{l}$ in lactating and $10,9 \pm 0,55 \mu \mathrm{mol} / \mathrm{l}$ - idle animals (tabl. 3). Deficiency of copper appeared in 5,6 and $11,1 \%$ animals, respectively.

Table 3. Content of microelements in serum blood of ewes under HODS

\begin{tabular}{|c|c|c|c|c|}
\hline Groups of animals & Biometric index & Manganese, $\mu \mathrm{mol} / \mathrm{l}$ & Zinc, $\mu \mathrm{mol} / /$ & Copper, $\mu \mathrm{mol} / \mathrm{I}$ \\
\hline \multicolumn{5}{|l|}{ Lactating } \\
\hline Clinically healthy & Lim & $0,86-1,52$ & $15,8-18,2$ & $10,3-15,2$ \\
\hline$(n=16)$ & $M \pm m$ & $1,1 \pm 0,04$ & $16,8 \pm 0,16$ & $12,2 \pm 0,4$ \\
\hline Animals & $\operatorname{Lim}$ & $0,88-1,51$ & $14,3-19,1$ & $8,9-16,6$ \\
\hline $\operatorname{HODS}(n=18)$ & $\mathrm{M} \pm \mathrm{m}$ & $1,25 \pm 0,01^{*}$ & $16,9 \pm 0,32$ & $11,2 \pm 0,37$ \\
\hline \multicolumn{5}{|l|}{ Idle } \\
\hline Clinically & Lim & $0,86-1,21$ & $15,6-17,0$ & $9,8-14,2$ \\
\hline$(n=7)$ & $M \pm m$ & $1,06 \pm 0,06$ & $16,5 \pm 0,27$ & $11,4 \pm 0,76$ \\
\hline Animals & Lim & $0,86-1,54$ & $14,7-17,2$ & $8,3-13,2$ \\
\hline $\operatorname{HODS}(n=9)$ & $\mathrm{M} \pm \mathrm{m}$ & $1,07 \pm 0,03$ & $15,9 \pm 0,29$ & $10,9 \pm 0,55$ \\
\hline
\end{tabular}

Note. ${ }^{*}-p<0,05$, in accordance with group of clinically healthy animals. 
The above mentioned materials confirm that HODS is very common for the sheep population. $7,6 \%$ of the animals showed to have this syndrome. Combined liver pathology with calcium-phosphorus metabolism, in addition to $100 \%$ hypocalcemia, is characterized by dysproteinemia in $96.6 \%$ of sheep and hyperenzymemia GGT $24,1 \%$. The last indicator is more specific for the idle animals and it makes $66,7 \%$.

The metabolic deficiency of trace elements in animal feeds is caused by the minerals deficiency and iron excess, which in high concentrations in the ratio playes a leading role of antagonist for copper and zinc [12, 13]. The low number of animals with the hypomaganemia signs is explained that ewes milk [14], contain less amount of manganese, considering that milk is a main source of its secretion for ruminants.

\section{Conclusion}

Hepatoosteodystrofic syndrome is widely spread in $7.6 \%$ of ewes' population. This pathology is caused by the lack of the metabolizable energy, crude and digestible protein, sugar, starch, calcium, phosphorus, copper, zinc, manganese in ratio; low ratio between easy digestible carbohydrates and digestible protein.

HODS is characterized by hypoalbuminemia in $79,3 \%$ of sheep by hypergammaglobulinemia - in $44,8 \%$ with the normal content of total protein in the blood serum (at 62,07 \%). Hypoactivity of GGT was detected in $48,3 \%$ of sick animals, with zinc deficiency of $22,2 \%$. The most informative indicator for the this syndrome is hypocalcemia, which is a common sign in $100 \%$ of ewes.

\section{Reference}

1. Levchenko, V.I. \& Sakhniuk, V.V. (1997) polimorbidnist' patologii u vysokoproduktyvnyh koriv [polymorbidity pathology of highly productive cows]. Visnyk bilotserkivs'kogo derzhavnogo agrarnogo universytetu - messenger of bila tserkva state agrarian university, vol. 3, 1, 89-92 [in ukrainian].

2. Kondrakhin I.P. (1998) polimorbidnost' vnutrennei patologii [polymorbidity of internal pathology]. Visnyk bilotserkivs'kogo derzhavnogo agrarnogo universytetu - messenger of bila tserkva state agrarian university, vol. 5, 1. 79-83 [in ukrainian].

3. Sitnichenko I.v. Porushennia mineralnogo obminu v ovets' u zoni kiivs'kogo polissia (diagnostyka, likuvannia, profilaktyka) [disturbance of mineral exchange sheep in zone of kyiv polissya (diagnostics, treatment, prophylaxis)]: extended abstract of candidate's thesis. Kyiv [in ukrainian].

4. Churnushkin b.o. Patogenez, diagnostyka ta likuvannia ovets', khvorykh na gepatodystrofiiu [pathogenesis, diagnostics and treatment of sheep ill with hepatodystrophy]. Extended abstract of candidate's thesis. Kyiv [in ukrainian].

5. Senchuk I.V. Polimorbidnist': ketoz ta gepatodystrofiia vivtsematok (etiologiia, diagnostyka, profilaktychna terapiia) [Polymorbidity: ketosis and liver dystrophy of ewes (ethyology, diagnostics, prophylactic therapy)] Extended abstract of candidate's thesis. Kyiv [in Ukrainian].

6. Kamyshnikov V.S. (2003) Kliniko-biokhimicheskaya laboratornaia diagnostika [Clinical-biochemical laboratory diagnostics]. Minsk: Interpresservis (Vol. 1-2).

7. Provatorov, G.V., Ladyka, V.I., Bondarchuk, L.V., et al. (2007) Normy godivli i pozhyvnist' kormiv dlia riznyh vydiv sil's'kogospodars'kykh tvaryn : dovidnyk [Normatives of feeding, rations and nutritional value for different species of agricultural animals]. Sumy: Universytets'ka knyga [in Ukrainian].

8. Provatorov, G.V., Ladyka, V.I., Bondarchuk, L.V. (2009) Normy godivli, ratsiony i pozhyvnist' kormiv dlia riznykh vydiv sil's'kogospodars'kykh tvaryn: dovidnyk [Normatives of feeding, rations and nutritional value for different species of agricultural animals]. Sumy: Universytets'ka knyga [in Ukrainian].

9. Bogdanov, G.O., Kandyba, V.M., Ibatulin, I.I., et al. (2012) Teoriia i praktyka normovanoi godivli velykoi rogatoi khudoby: Monografia [Theory and practice normative feeding of cattle: monography]. V.M. Kandyba, I.I. Ibatulin, V.I. Kostenko (Ed.). Zhytomyr [in Ukrainian].

10. Vlizlo ,V.V., Fedoruk, R.S., Ratich, I.B., et I. (2012) Laboratorni metody doslidzhen' u biologii, tvarynnytstvi ta veterynarnii medytsyni: dovidnyk [Laboratory methods of researches in biology, animal husbandury and veterinary medicine]. V.V. Vlizlo (Ed.). Lviv: SPOLOM. 
11. Levchenko, V.I., Golovakha, V.I., Kondrakhin, I.P., et al. (2010) Metody laboratornoi klinichnoi diagnostyky khvorob tvaryn [Methods of laboratory clinical diagnostics of animal diseases]. Kyiv: Agrarna osvita [in Ukrainian].

12. Phillippo, M., Himphries, W.R., \& Garthwaite, P.H. (1987) The effect of dietary molybdenum and iron on copper status and growth in cattle. Journal of Agricultural Science Cambrige Core, Vol. 109, 315-320.

13. Trakhtenberg, I.M., Chekman, I.S., Linnik, V.O. et al. (2013) Vzaiemodia mikroelementiv: biologichnyi, medychnyi i sotsial'nyi aspekty [Interaction of microelements: biological, medical and social aspects]. Visnyk NAN Ukrainy -Messenger of NAS of Ukraine, 6, 11-20 [in Ukrainian].

14. Merlin Junior I.A., Santos J.S., Costa L.G., et al. (2015) Sheep milk: physical-chemical characteristics and microbiological quality. Archives of Latinoamerican Nutrition, Vol. 65, 3, 193-198.

15. Ho S.Y., Miller W.J., Gentry R.P. et al. (1984) Effects of high, but nontoxic dietary manganese and iron on their metabolism by calves. Journal of Dairy Science, Vol. 67, 7, 1489-1495. 